\title{
Naphthochromenes and Related
}

\section{Constituents from the Tubers of Sinningia}

\section{allagophylla}

Dilamara R. Scharf ${ }^{\dagger 1}$, Maria H. Verdan ${ }^{\dagger}$, Marcos A. Ribeiro ${ }^{+}$, Edesio L. Simionatto ${ }^{\S}$,

Eduardo L. Sá ${ }^{\dagger}$, Marcos J. Salvador ${ }^{\perp}$, Andersson Barison ${ }^{\dagger}$, and Maria E. A. Stefanello ${ }^{\dagger}$

`Universidade Federal do Paraná, Departamento de Química, 81530-900, Curitiba, PR, Brazil,

${ }^{t}$ Universidade Estadual de Campinas, Instituto de Química, Laboratório de Química de Coordenação, 13083-970, Campinas, SP, Brazil,

${ }^{\S}$ Universidade Regional de Blumenau, Departamento de Química, 89030-903, Blumenau, SC, Brazil,

${ }^{\perp}$ Universidade Estadual de Campinas, Instituto de Biologia, Departamento de Biologia Vegetal, PPG- BTPB and PPG-BV, 13083-970, Campinas, SP, Brazil.

${ }^{1}$ Corresponding author: Tel: +55 47 3221-6099 Email: dilaquimica@,hotmail.com; Email: elida@ufpr.br (M. E. A. Stefanello) 
Figure S1 Structures of known compounds isolated of S. allagophylla. 3

Figure S2 $\quad{ }^{1} \mathrm{H}$ NMR (400 MHz, $\mathrm{CDCl}_{3}$ ) spectrum of the new compound $\mathbf{1 .} 4$

Figure S3 HSQC spectrum $\left(400 \mathrm{MHz}, \mathrm{CDCl}_{3}\right)$ of the new compound 1.

Figure S4 HMBC spectrum $\left(400 \mathrm{MHz}, \mathrm{CDCl}_{3}\right)$ of the new compound $\mathbf{1}$. 5

Figure S5 UV spectrum of the new compound $\mathbf{1}$ 5

Figure S6 $\quad{ }^{1} \mathrm{H}$ NMR $\left(600 \mathrm{MHz}, \mathrm{CDCl}_{3}\right)$ spectrum of the new compound 2.

Figure S7 HSQC spectrum (600 MHz, $\left.\mathrm{CDCl}_{3}\right)$ of the new compound 2.

Figure S8 $\mathrm{HMBC}$ spectrum $\left(600 \mathrm{MHz}, \mathrm{CDCl}_{3}\right)$ of the new compound 2.

$\begin{array}{lll}\text { Figure S9 UV spectrum of the new compound } 2 . & 7\end{array}$

Figure S10 $\quad{ }^{1} \mathrm{H}$ NMR (400 MHz, $\left.\mathrm{CDCl}_{3}\right)$ spectrum of the new compound 3.

Figure S11 HSQC spectrum (400 MHz, $\mathrm{CDCl}_{3}$ ) of the new compound 3.

Figure $\mathrm{S} 12 \mathrm{HMBC}$ spectrum $\left(400 \mathrm{MHz}, \mathrm{CDCl}_{3}\right)$ of the new compound $\mathbf{3} .9$

Figure S13 UV spectrum of the new compound 3 . 9

Figure S14 ${ }^{1} \mathrm{H}$ NMR (400 MHz, $\left.\mathrm{CDCl}_{3}\right)$ spectrum of the new compound 4.

Figure S15 HSQC spectrum (400 MHz, $\left.\mathrm{CDCl}_{3}\right)$ of the new compound 4.

Figure S16 $\mathrm{HMBC}$ spectrum $\left(400 \mathrm{MHz}, \mathrm{CDCl}_{3}\right)$ of the new compound 4.

Figure S17 UV spectrum of the new compound 4. 11

Figure S18 ${ }^{1} \mathrm{H}$ NMR (400 MHz, $\mathrm{CDCl}_{3}$ ) spectrum of the new compound $\mathbf{5}$.

Figure S19 HSQC spectrum (400 MHz, $\left.\mathrm{CDCl}_{3}\right)$ of the new compound $\mathbf{5}$.

Figure S20 HMBC spectrum (400 MHz, $\left.\mathrm{CDCl}_{3}\right)$ of the new compound $\mathbf{5}$.

$\begin{array}{lll}\text { Figure S21 UV spectrum of the new compound } 5 . & 13\end{array}$

Figure S22 ${ }^{1} \mathrm{H}$ NMR (400 MHz, $\mathrm{CDCl}_{3}$ ) spectrum of the new compound 6.

Figure S23 HSQC spectrum (400 MHz, $\mathrm{CDCl}_{3}$ ) of the new compound 6

Figure S24 HMBC spectrum (400 MHz, $\left.\mathrm{CDCl}_{3}\right)$ of the new compound 6.

Figure S25 UV spectrum of the new compound $6 . \quad 15$ 
<smiles>C[C@@H]1OC2=C(C(=O)c3ccccc3C2=O)C1(C)C</smiles>

alpha-dunnione

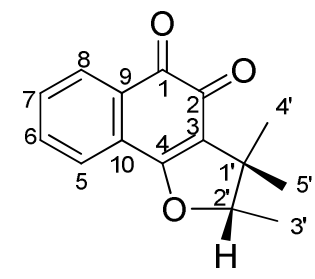

dunnione

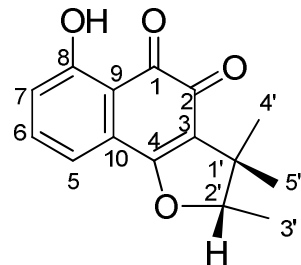

8-hydroxydunnione<smiles>COc1cc2c(c3ccccc13)OC(C)(C)C=C2</smiles>

lapachenole

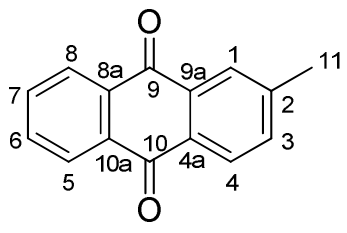

tectoquinone<smiles>O=C1c2ccc(I)cc2C(=O)c2ccc(O)cc21</smiles>

7-hydroxytectoquinone

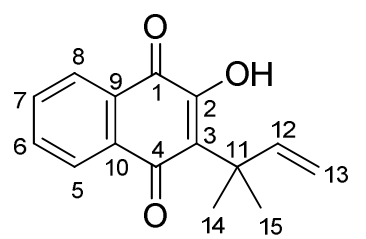

dunniol

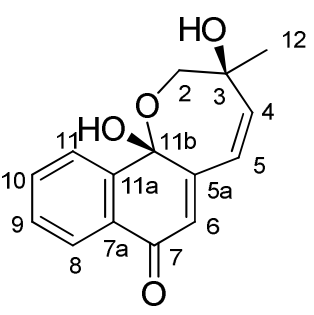

aggregatin $\mathrm{E}$

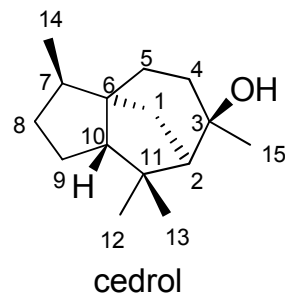

cedrol
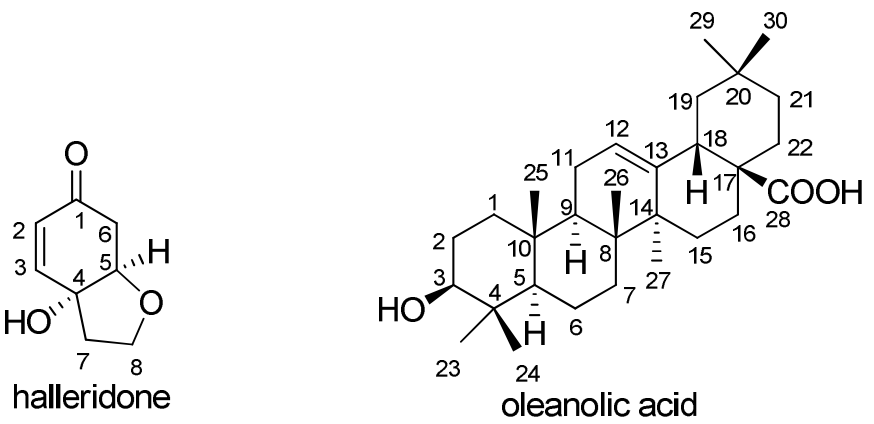

Figure S1 - Structures of known compounds isolated of S. allagophylla. 


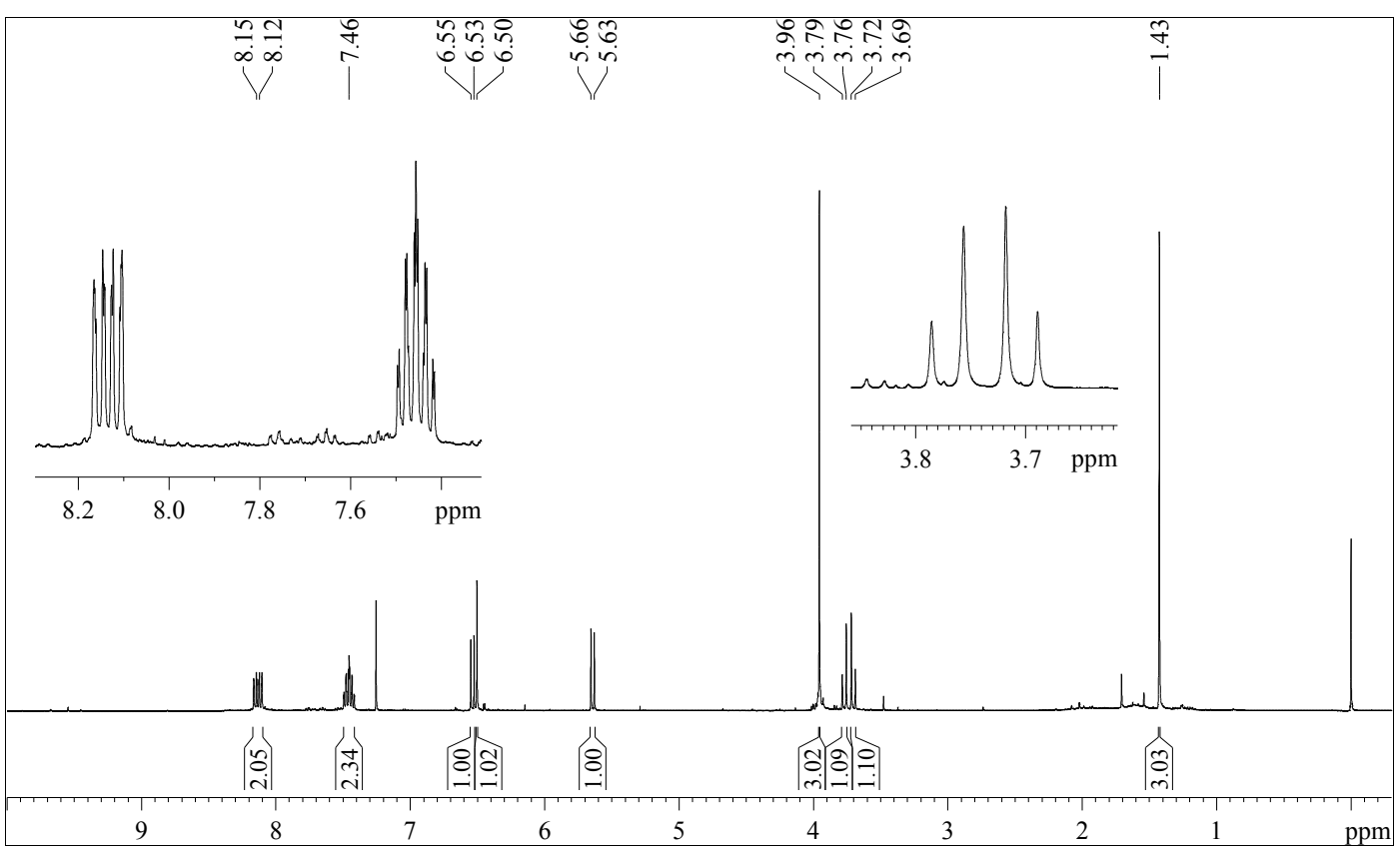

Figure S2. ${ }^{1} \mathrm{H}$ NMR $\left(400 \mathrm{MHz}, \mathrm{CDCl}_{3}\right)$ spectrum of the new compound 1.

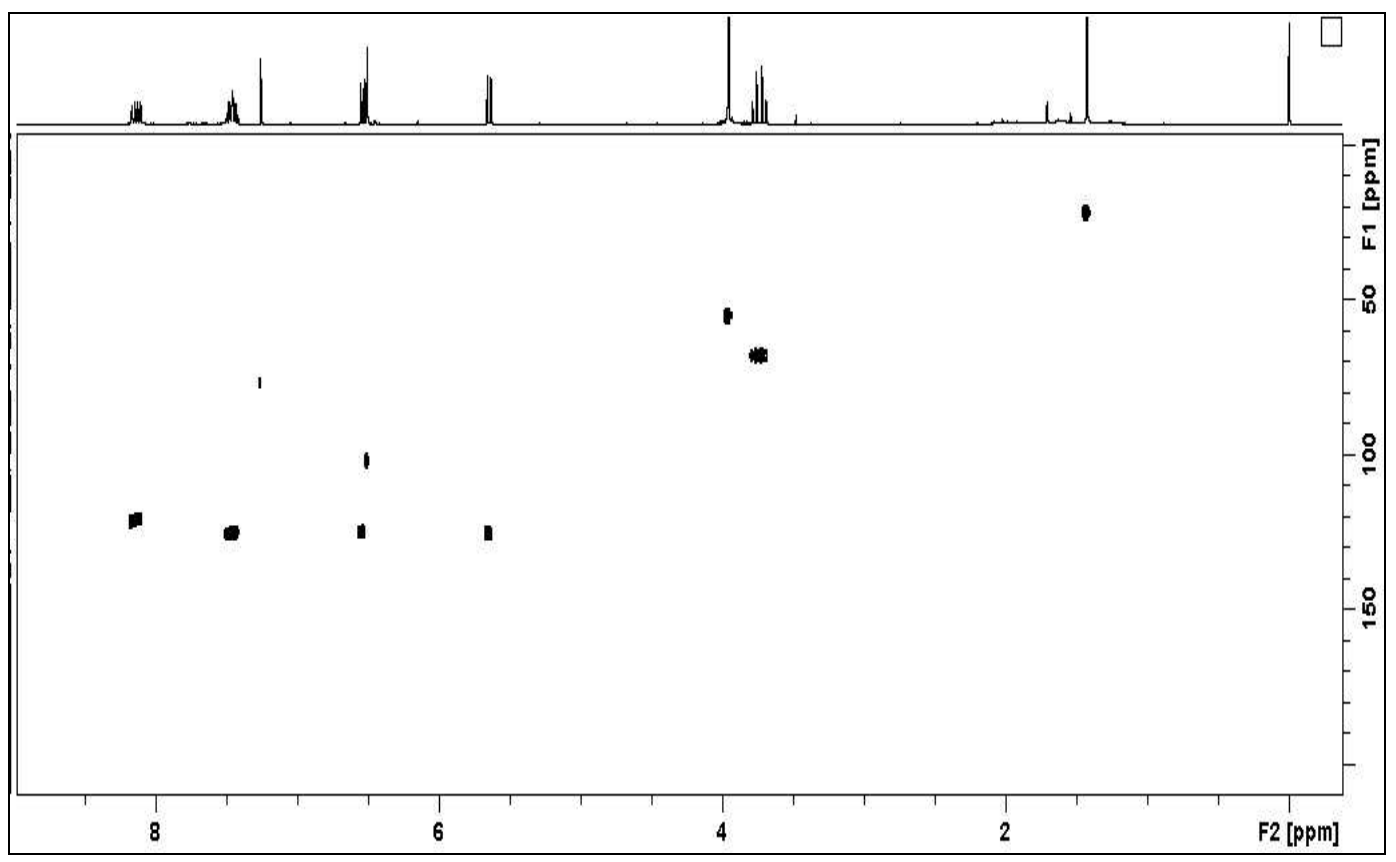

Figure S3. HSQC spectrum (400 MHz, $\mathrm{CDCl}_{3}$ ) of the new compound $\mathbf{1}$. 


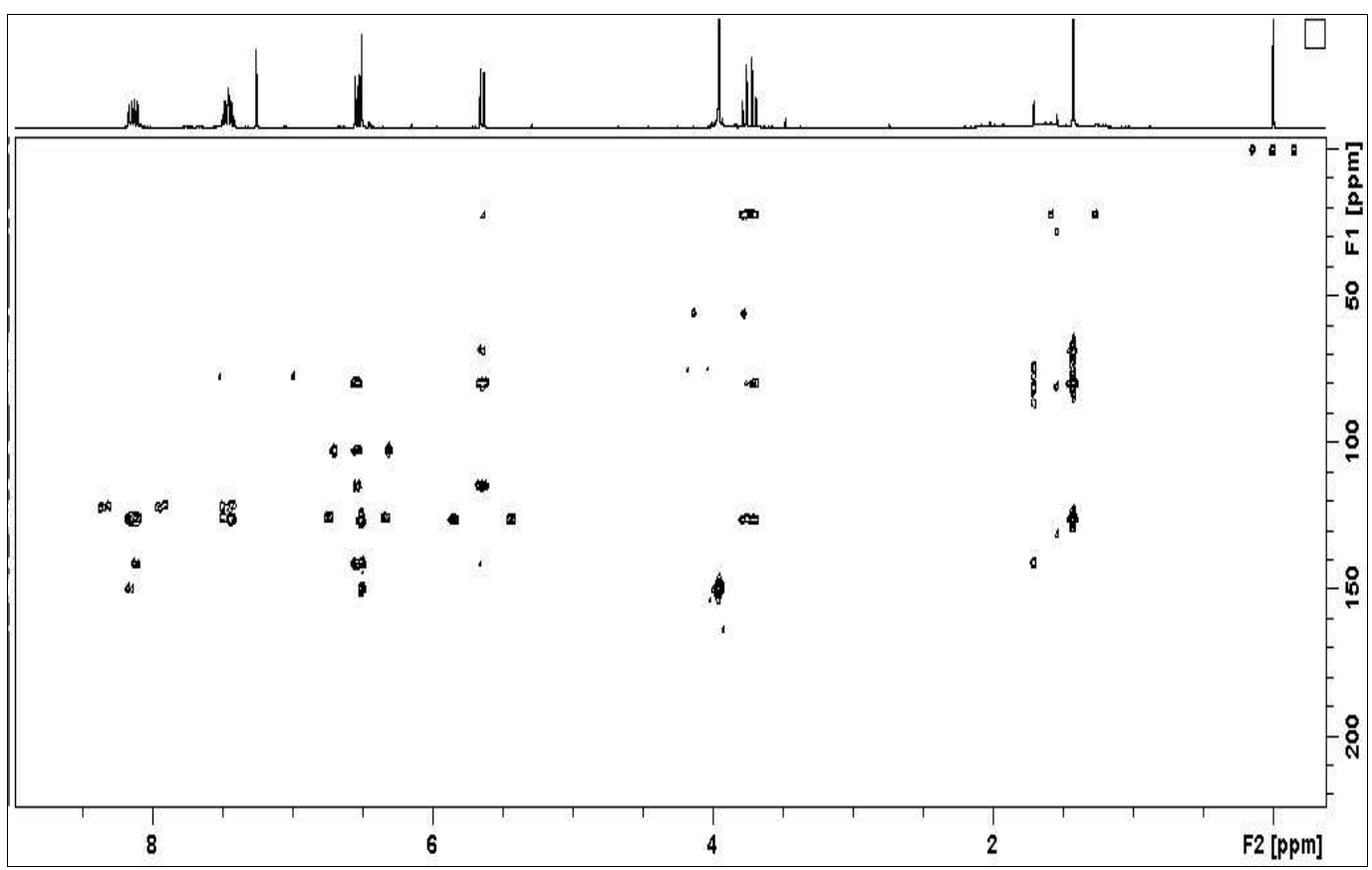

Figure S4. HMBC spectrum (400 MHz, $\mathrm{CDCl}_{3}$ ) of the new compound $\mathbf{1}$.

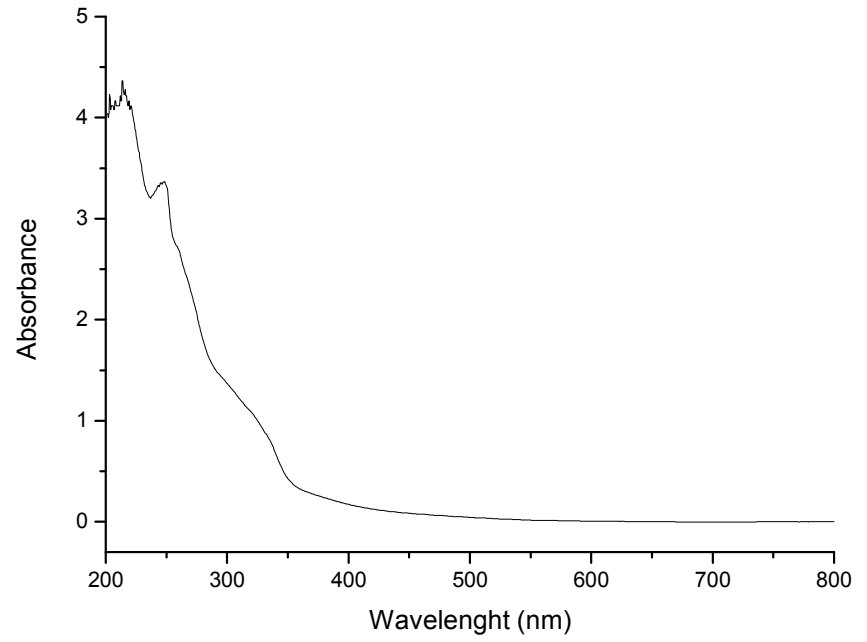

Figure S5. UV spectrum of the new compound 1. 


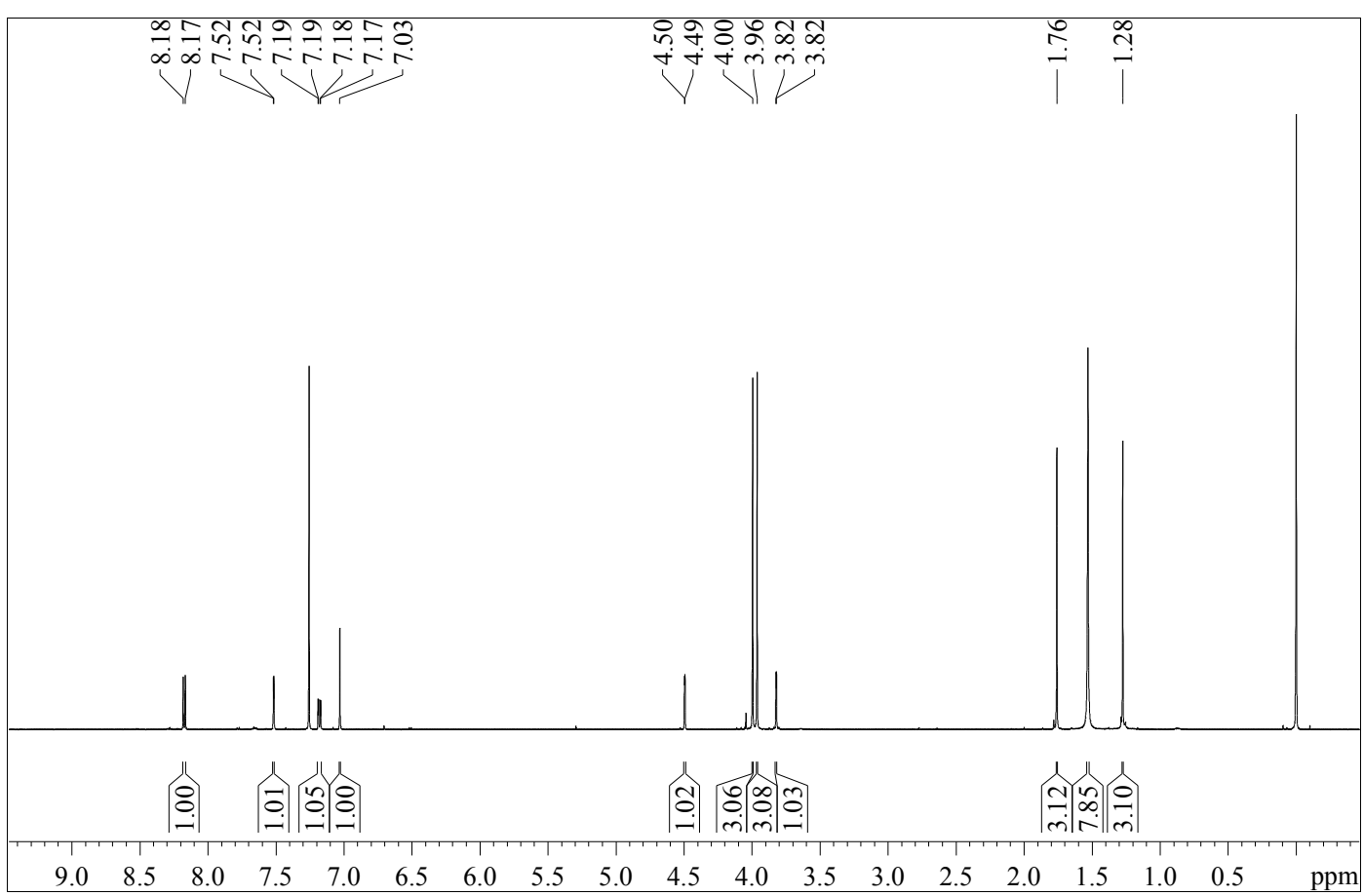

Figure S6. ${ }^{1} \mathrm{H}$ NMR $\left(600 \mathrm{MHz}, \mathrm{CDCl}_{3}\right)$ spectrum of the new compound 2.

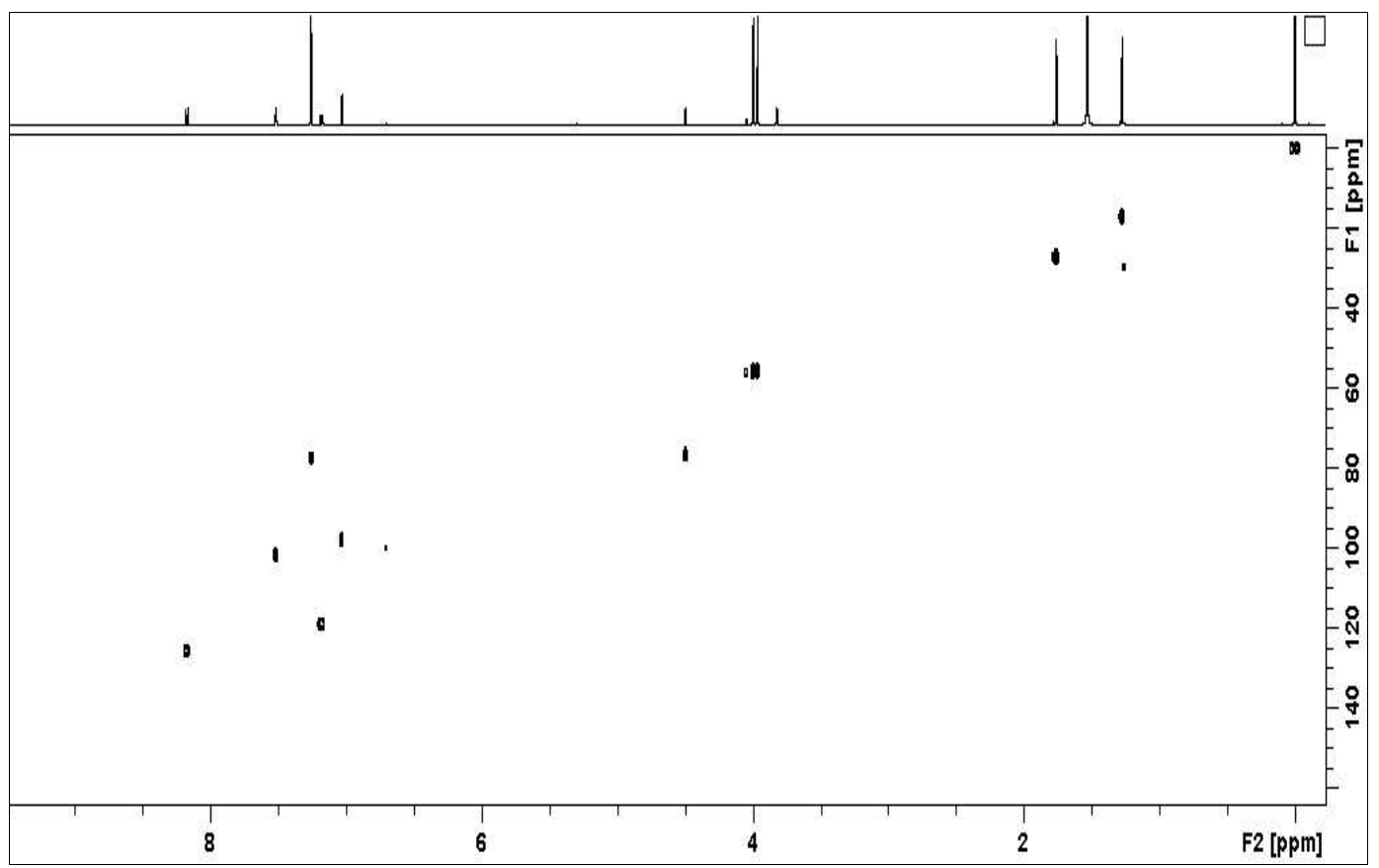

Figure S7. HSQC spectrum $\left(600 \mathrm{MHz}, \mathrm{CDCl}_{3}\right)$ of the new compound 2. 


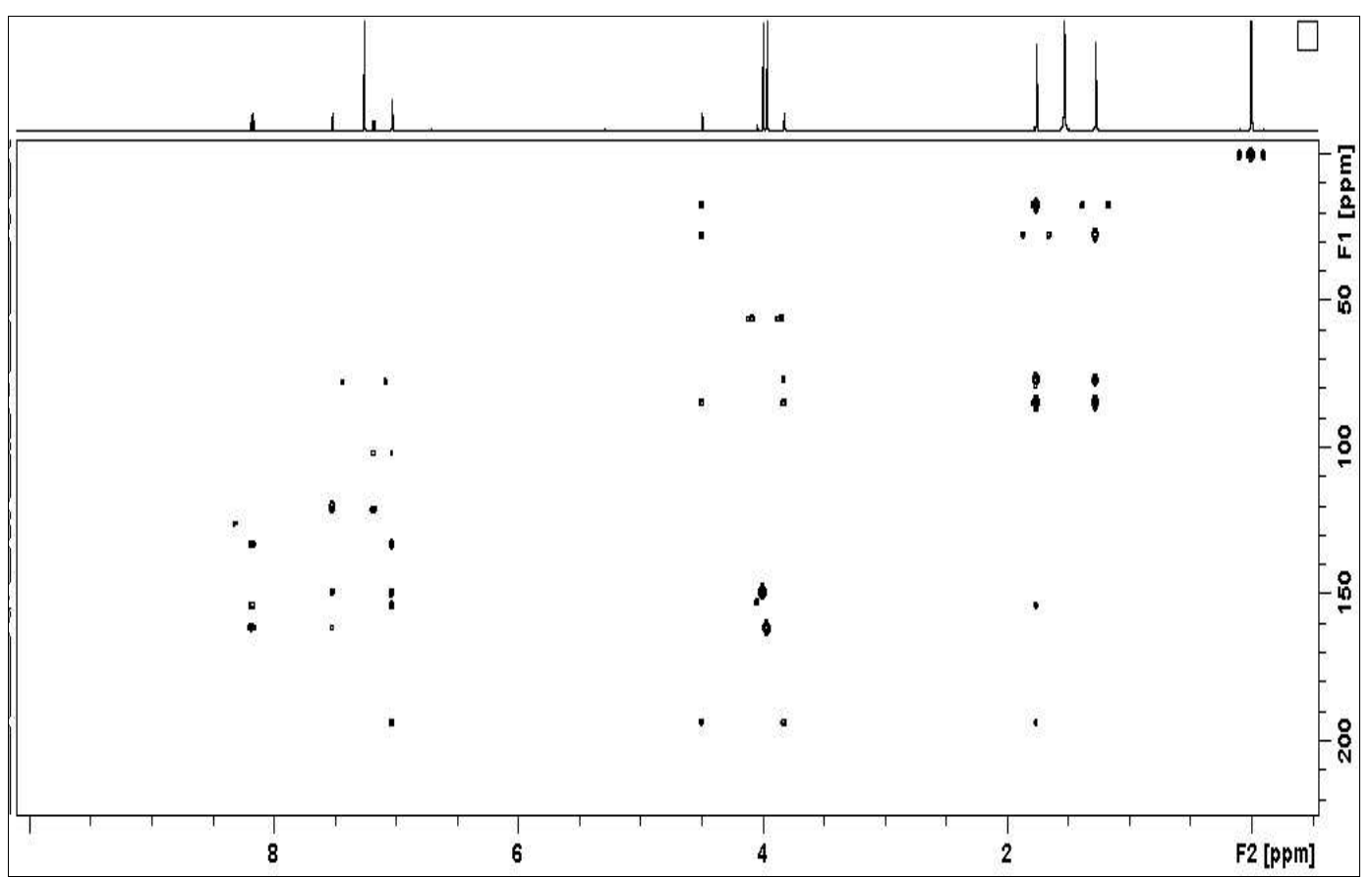

Figure S8. HMBC spectrum $\left(600 \mathrm{MHz}, \mathrm{CDCl}_{3}\right)$ of the new compound 2.

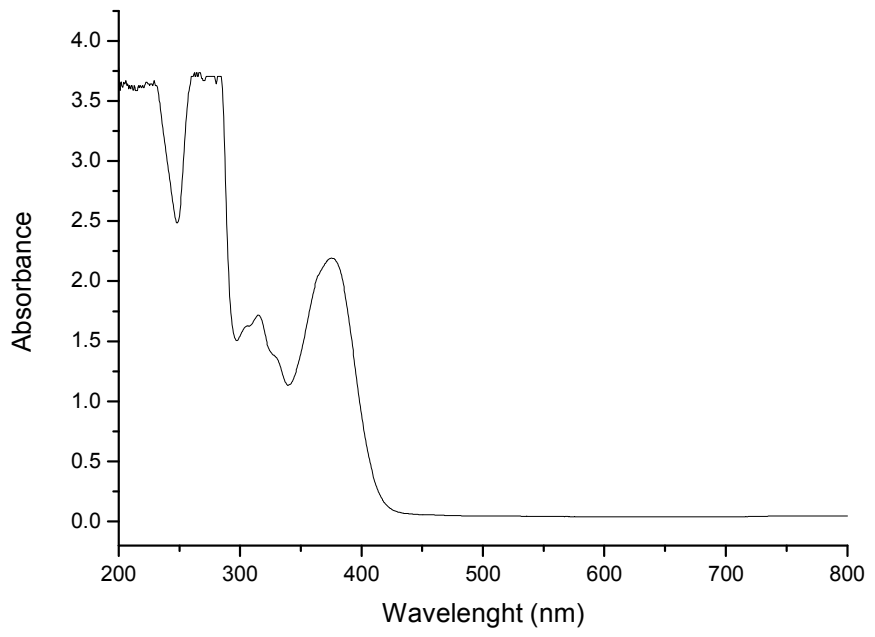

Figure S9. UV spectrum of the new compound 2. 


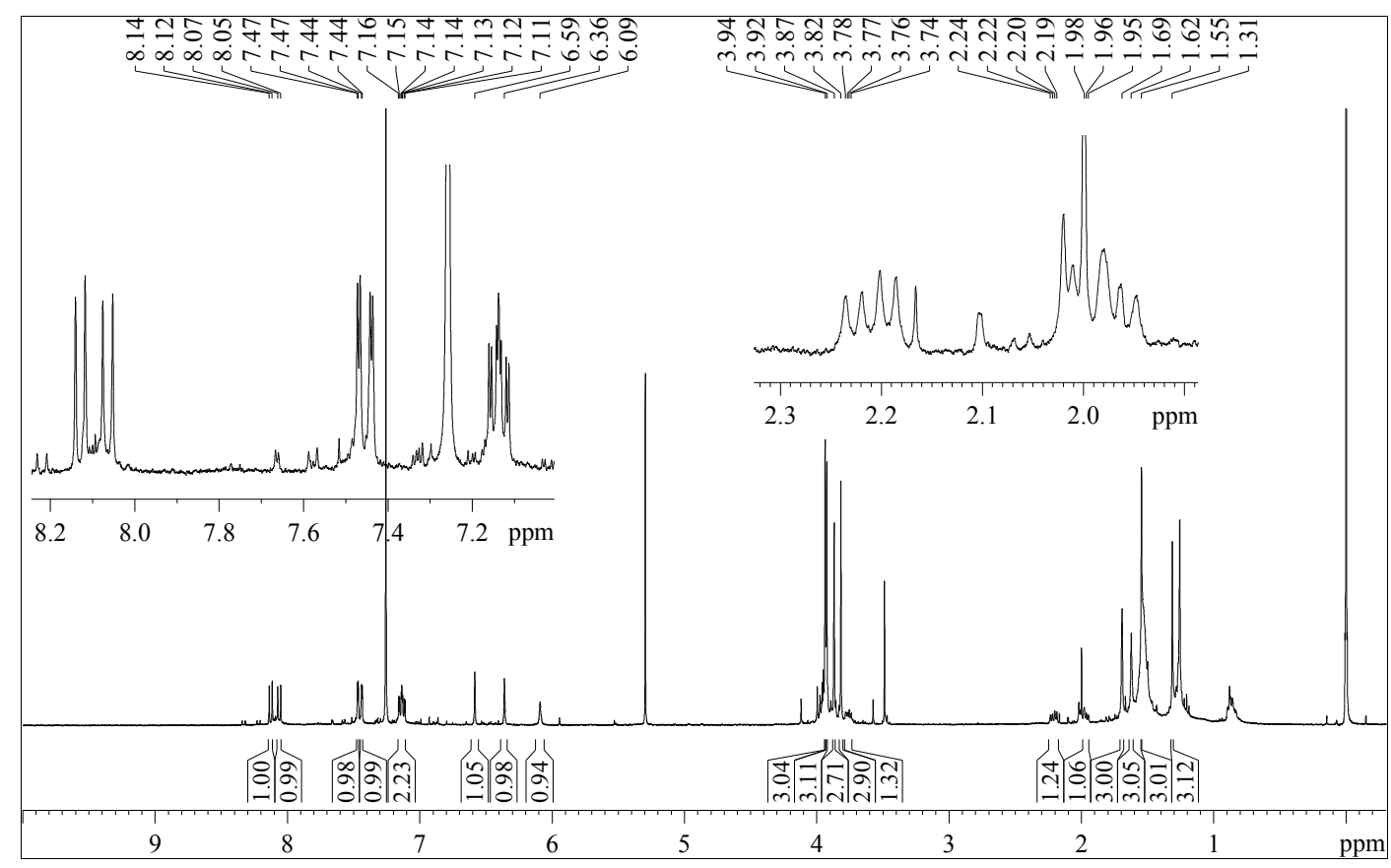

Figure S10. ${ }^{1} \mathrm{H}$ NMR $\left(400 \mathrm{MHz}, \mathrm{CDCl}_{3}\right)$ spectrum of the new compound 3.

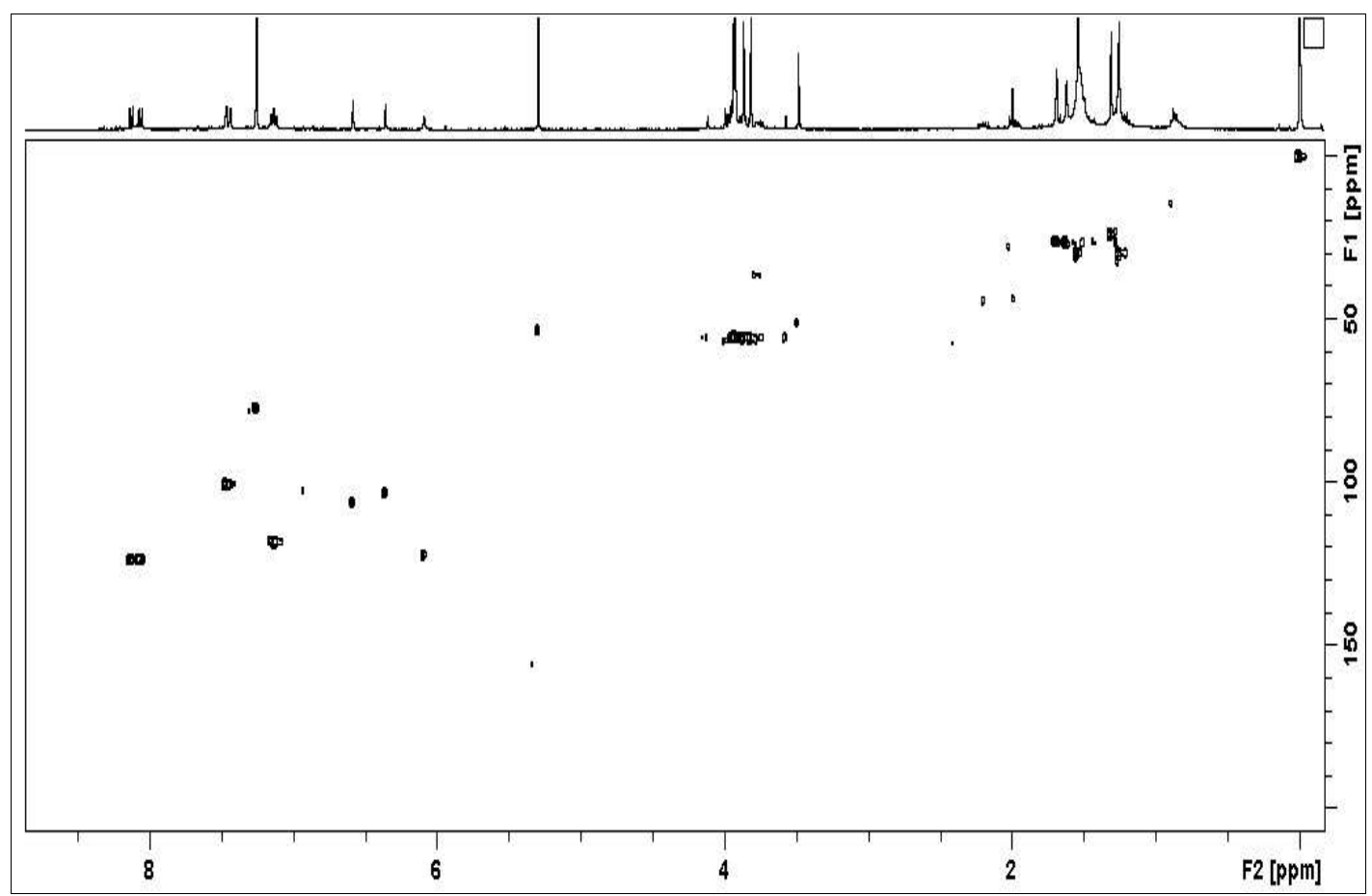

Figure S11. HSQC spectrum (400 $\left.\mathrm{MHz}, \mathrm{CDCl}_{3}\right)$ of the new compound 3 . 


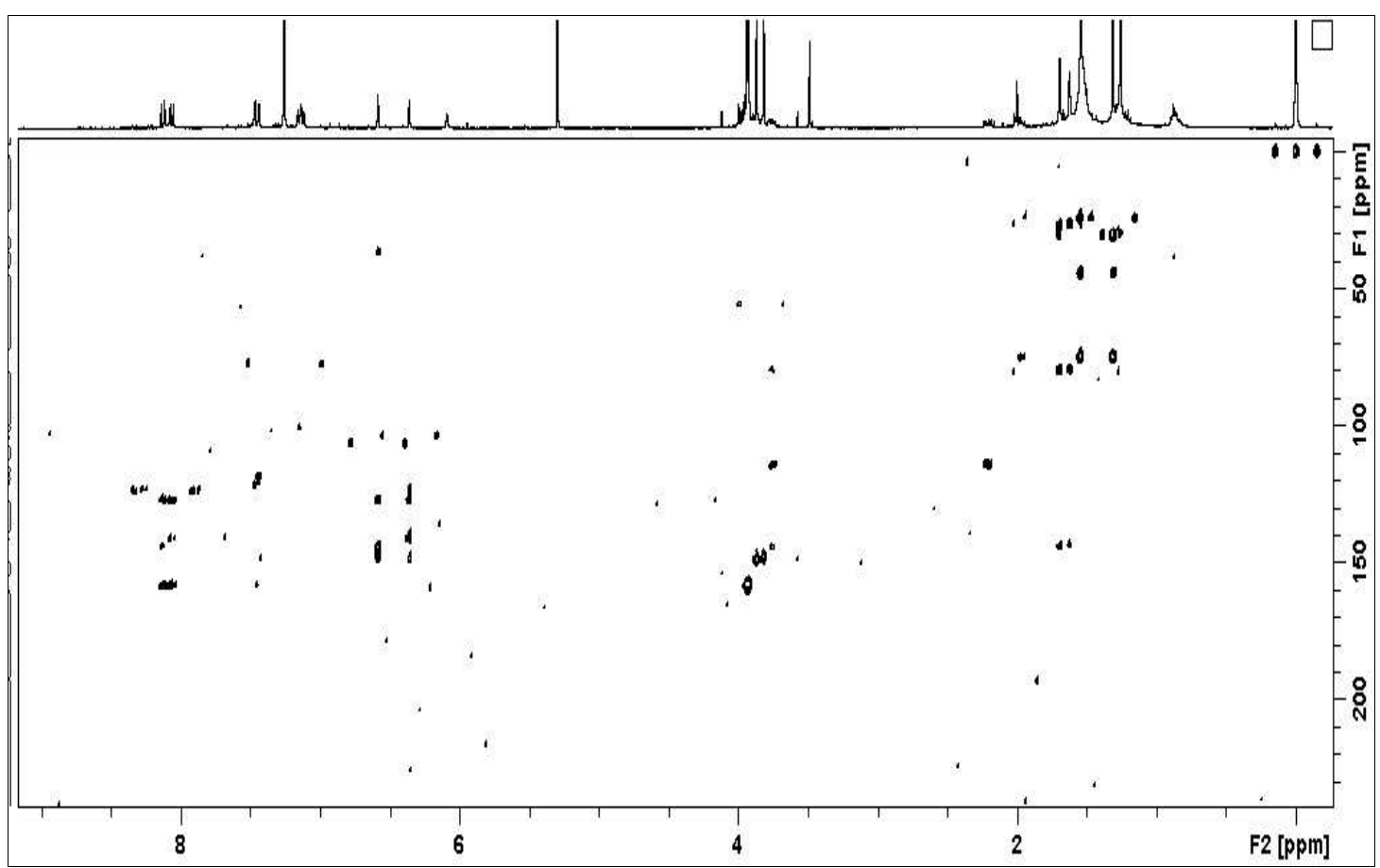

Figure S12. $\mathrm{HMBC}$ spectrum $\left(400 \mathrm{MHz}, \mathrm{CDCl}_{3}\right)$ of the new compound 3.

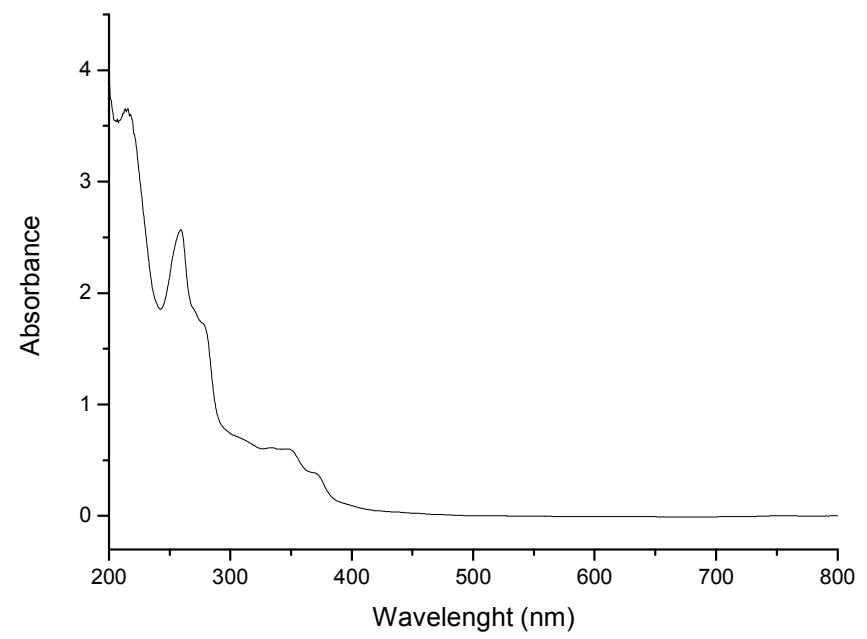

Figure S13. UV spectrum of the new compound 3. 


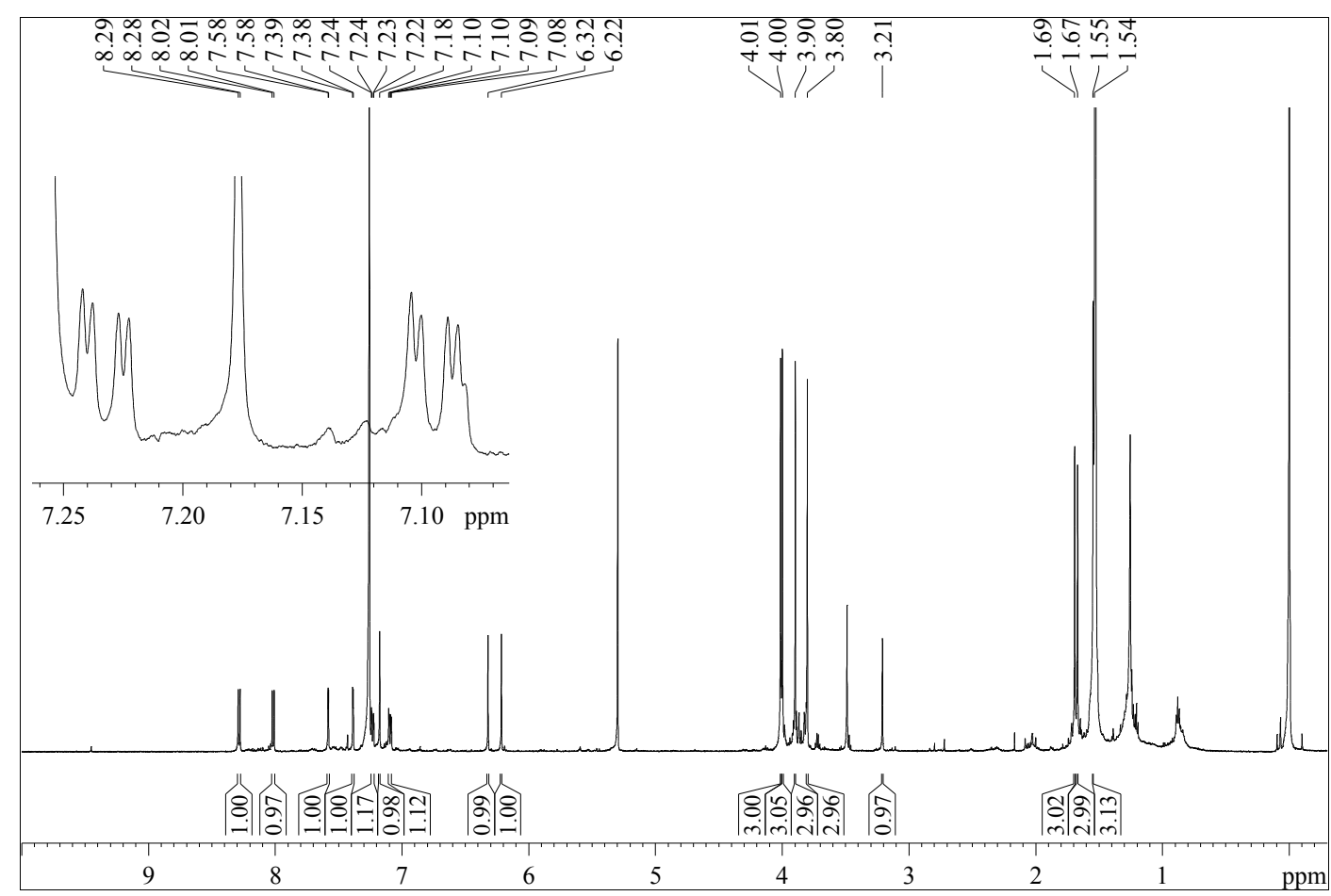

Figure S14. ${ }^{1} \mathrm{H}$ NMR (400 MHz, $\mathrm{CDCl}_{3}$ ) spectrum of the new compound 4.

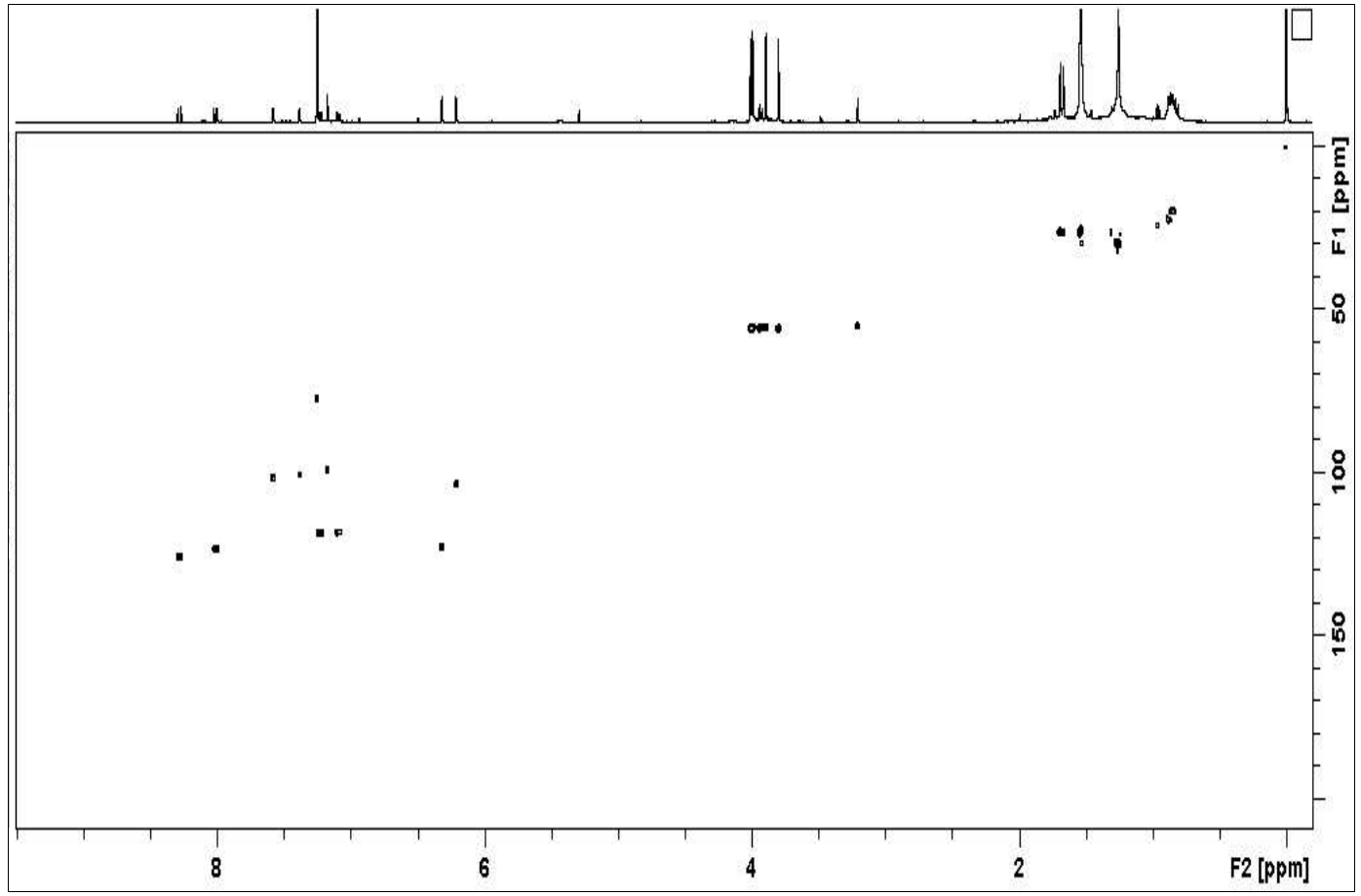

Figure S15. HSQC spectrum (400 MHz, $\mathrm{CDCl}_{3}$ ) of the new compound 4. 


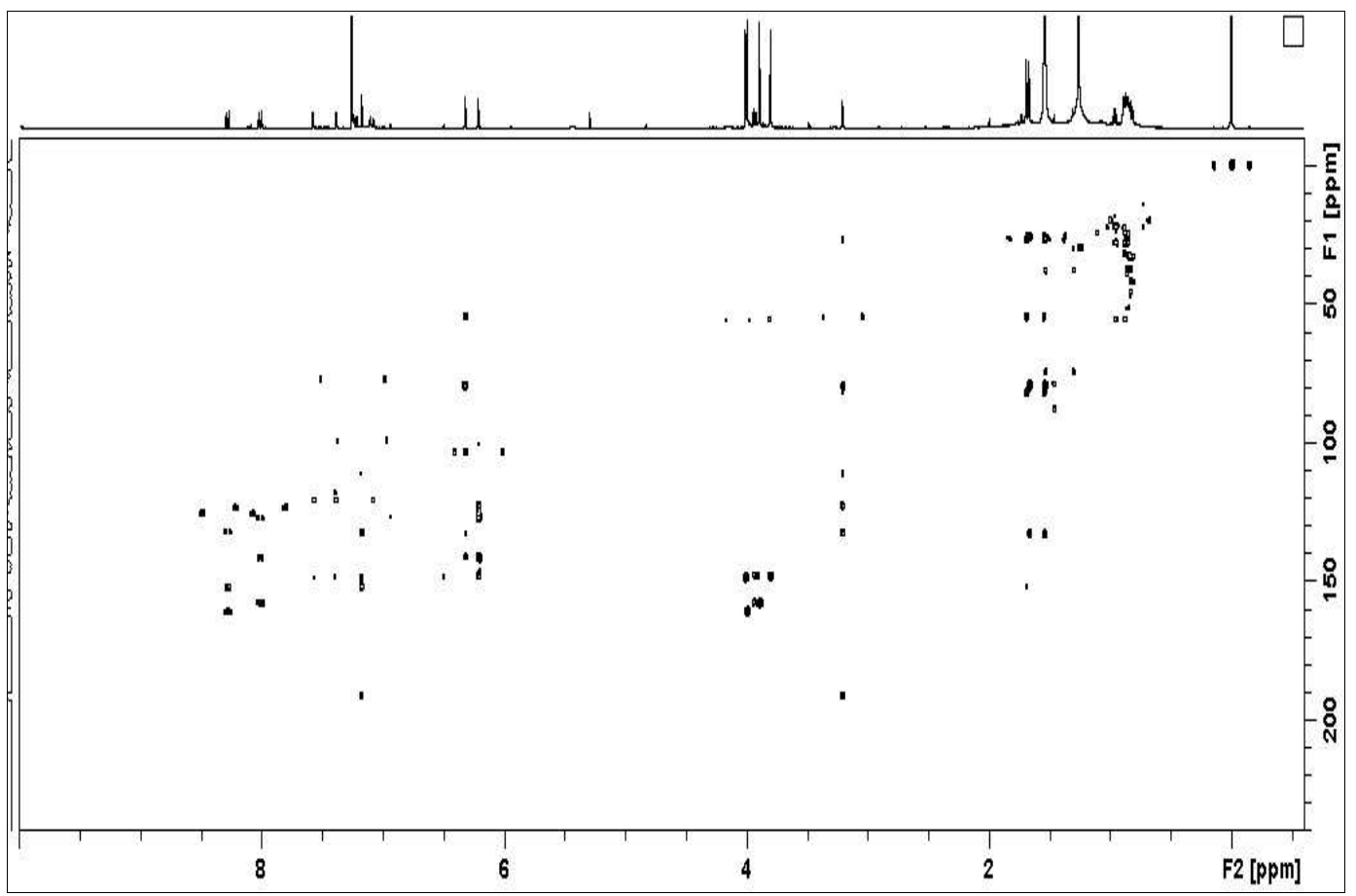

Figure S16. HMBC spectrum $\left(400 \mathrm{MHz}, \mathrm{CDCl}_{3}\right)$ of the new compound 4.

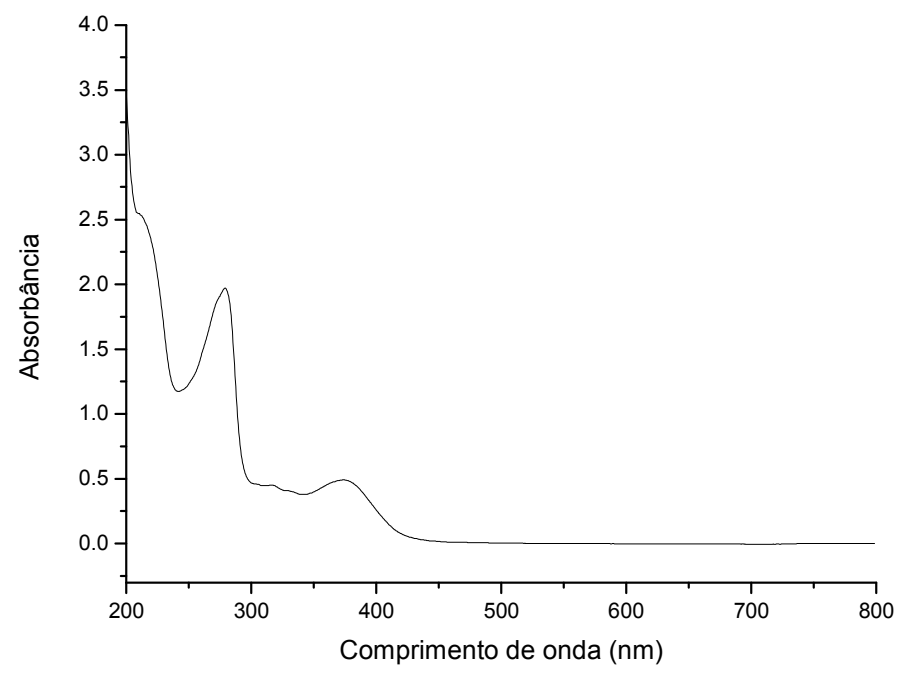

Figure S17. UV spectrum of the new compound 4. 


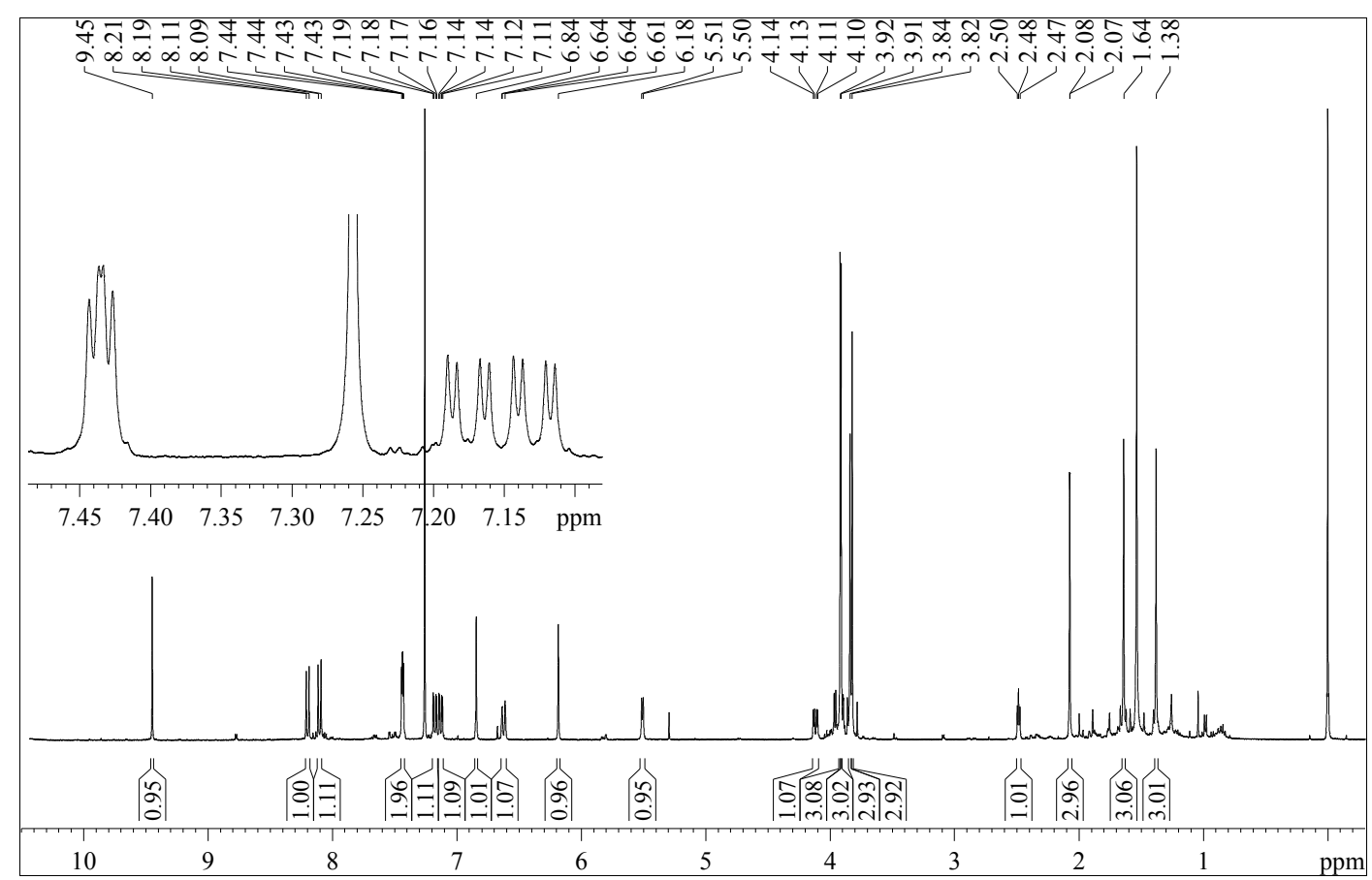

Figure S18. ${ }^{1} \mathrm{H}$ NMR $\left(400 \mathrm{MHz}, \mathrm{CDCl}_{3}\right)$ spectrum of the new compound 5.

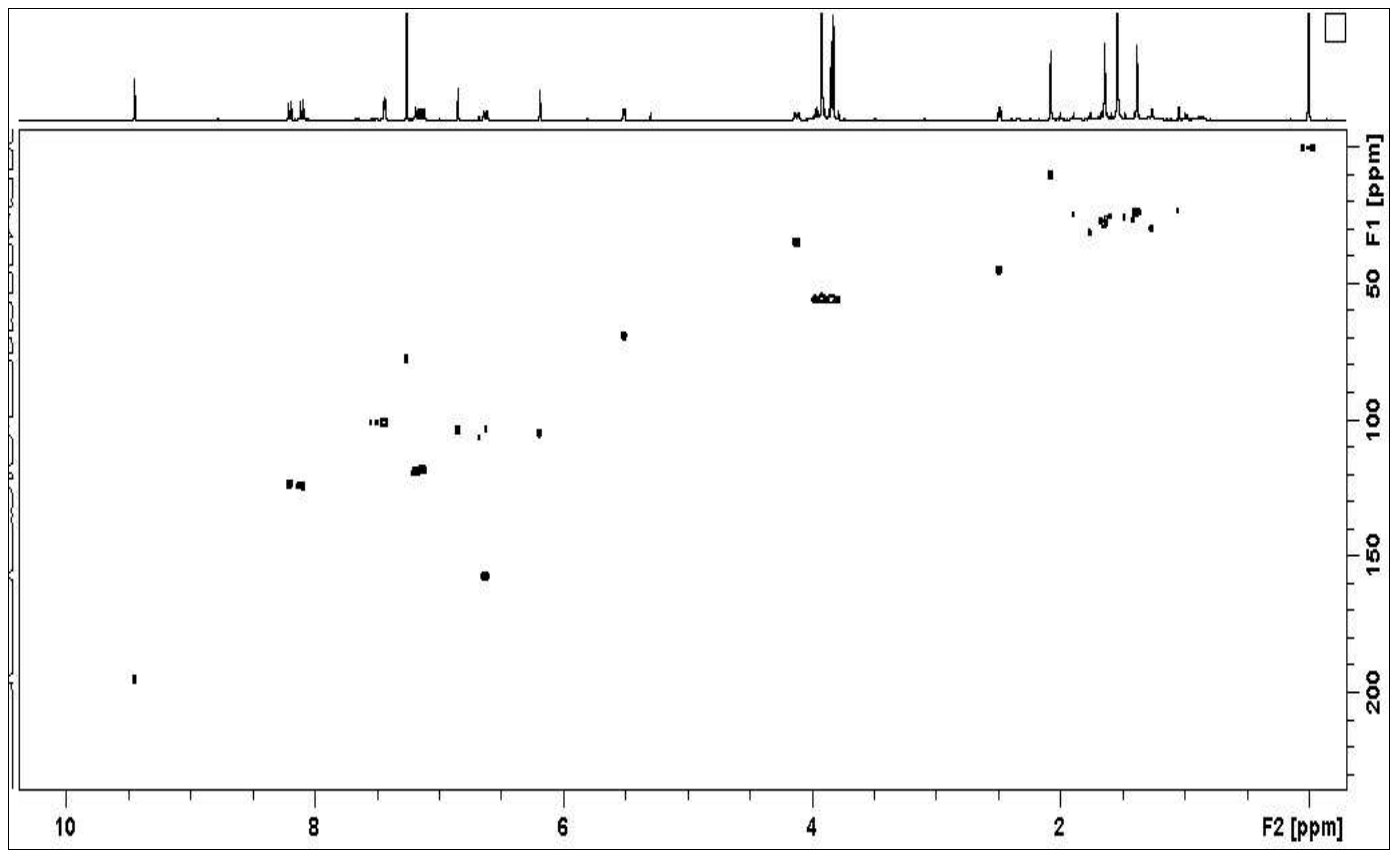

Figure S19. HSQC spectrum (400 $\left.\mathrm{MHz}, \mathrm{CDCl}_{3}\right)$ of the new compound $\mathbf{5}$. 


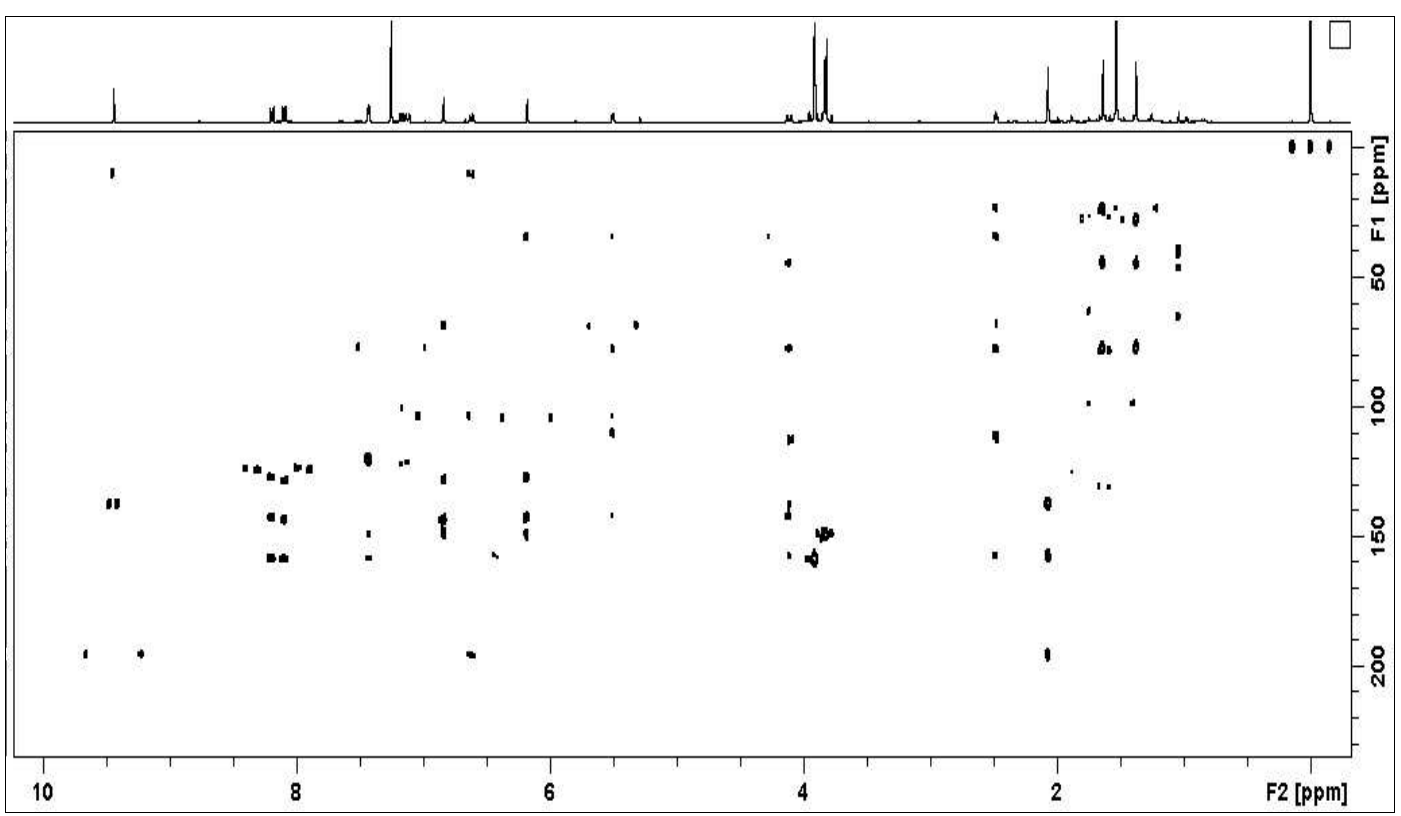

Figure S20. HMBC spectrum (400 MHz, $\left.\mathrm{CDCl}_{3}\right)$ of the new compound $\mathbf{5}$.

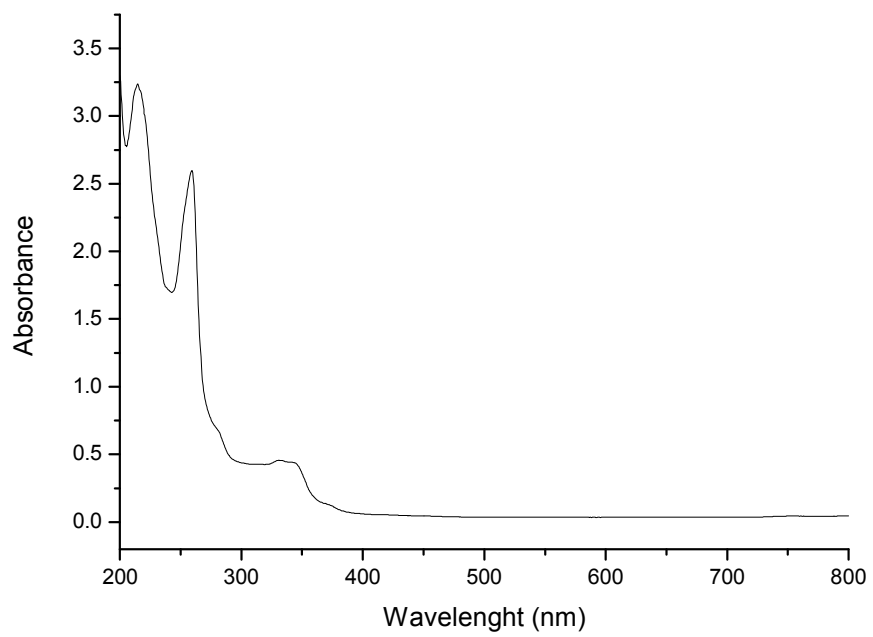

Figure S21. UV spectrum of the new compound 5. 


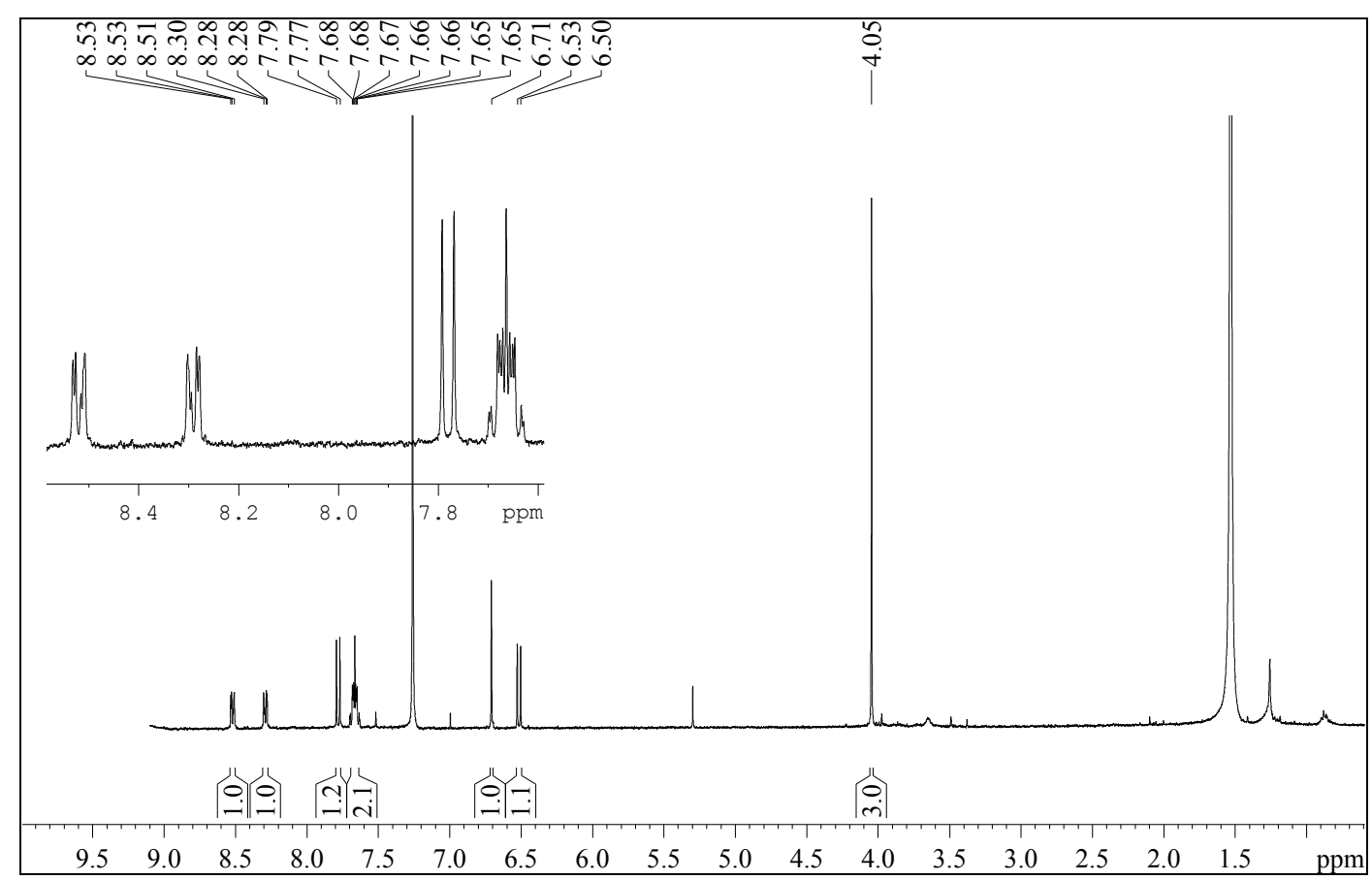

Figure S22. ${ }^{1} \mathrm{H}$ NMR $\left(400 \mathrm{MHz}, \mathrm{CDCl}_{3}\right)$ spectrum of the new compound 6.

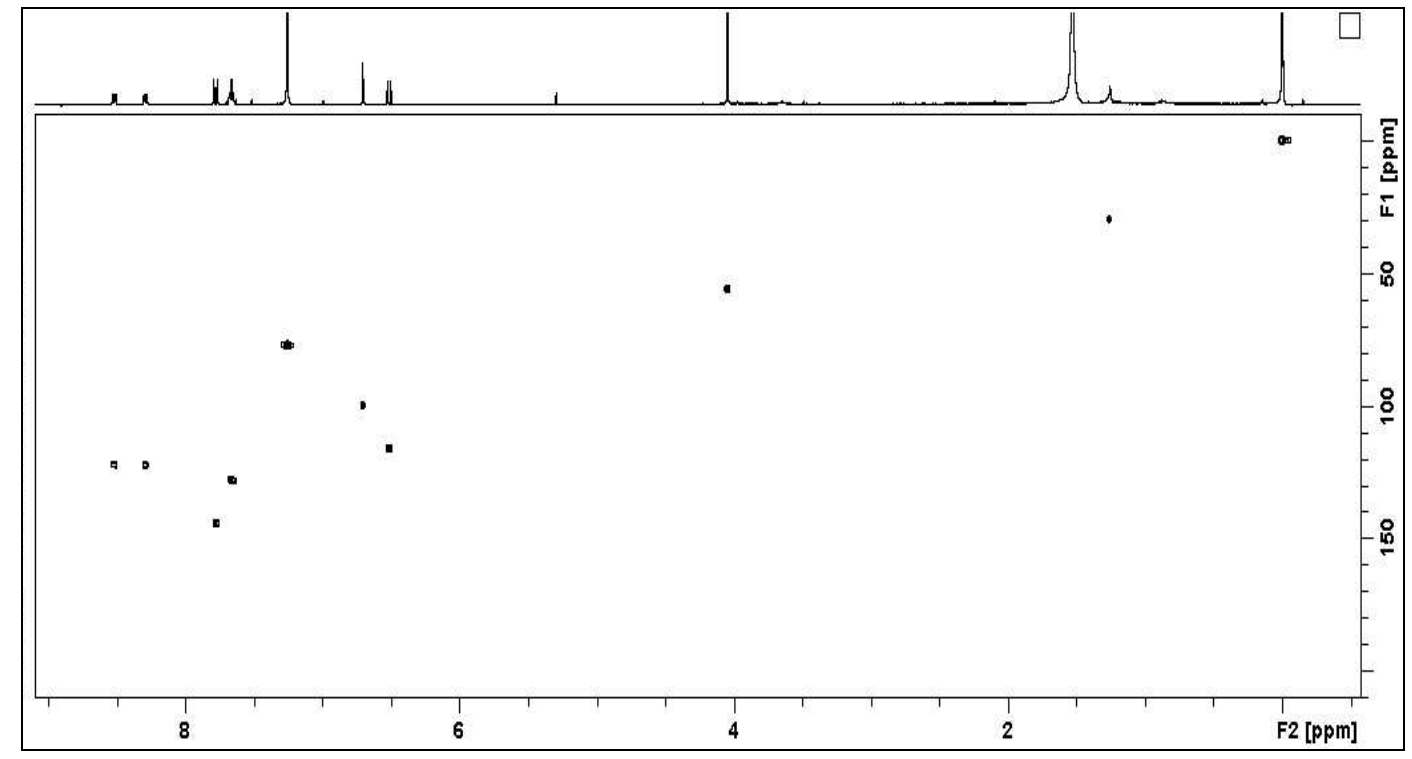

Figure S23. HSQC spectrum (400 MHz, $\left.\mathrm{CDCl}_{3}\right)$ of the new compound 6. 


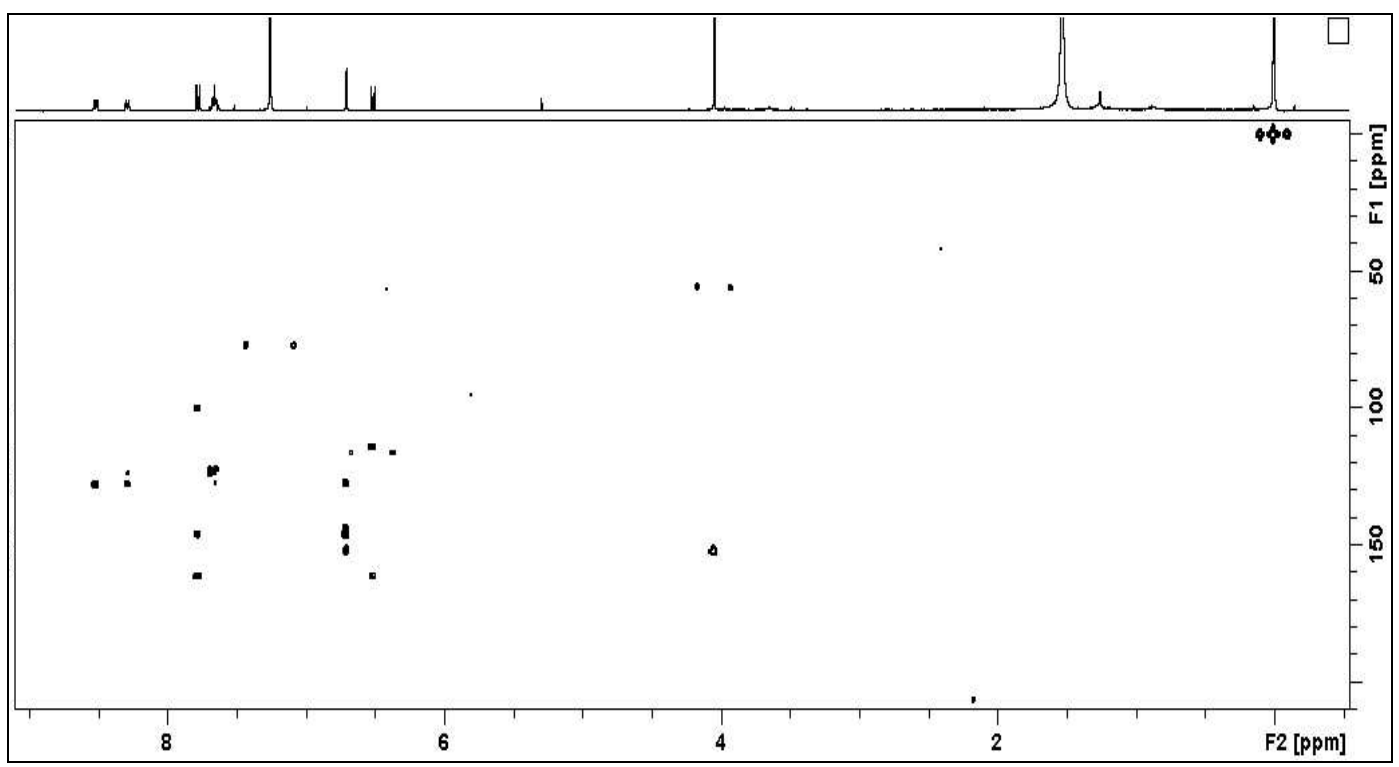

Figure S24. HMBC spectrum (400 MHz, $\left.\mathrm{CDCl}_{3}\right)$ of the new compound 6.

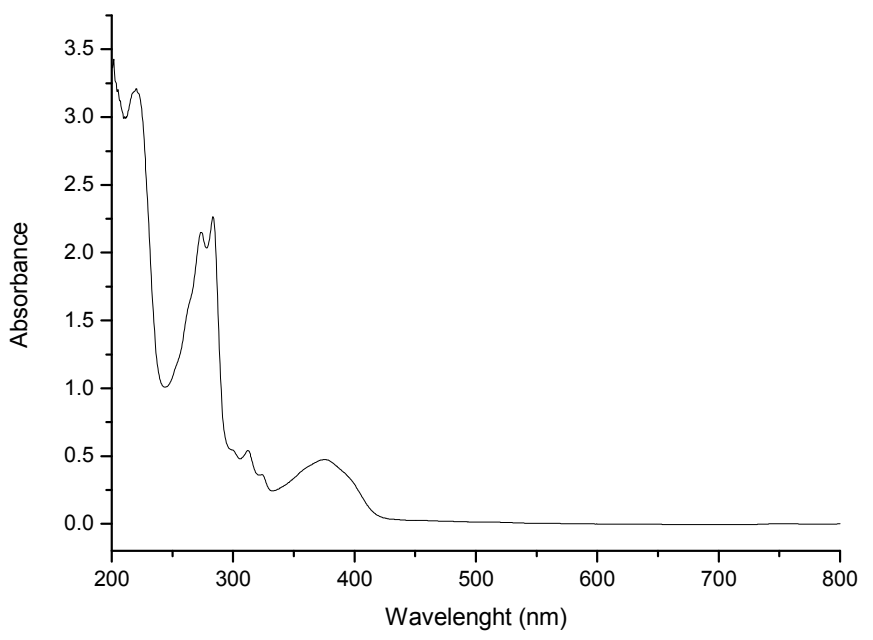

Figure S25. UV spectrum of the new compound 6. 